\title{
ELECTROCHEMICAL OXIDATION OF IODIDE DISSOLVED IN SODIUM-NITRATE-POTASSIUM-NITRATE EUTECTIC MELT ON A PLATINUM ROTATING DISK ELECTRODE*
}

\author{
W. E. Triaca, H. A. Videla and A. J. Arvía \\ División Electroquímica, Instituto Superior de Investigaciones, Facultad de \\ Ciencias Exactas, Universidad Nacional de La Plata, La Plata, Argentina
}

\begin{abstract}
The $E / I$ curve related to the electrochemical oxidation of iodide dissolved in molten nitrates on a platinum rotating disk electrode involves two anodic waves. The first corresponds to a reversible two-electron process and the second to a reversible one-electron process. A definite ratio between the anodic limiting currents is established suggesting that the second anodic wave is not independent from the first one. The parameters related to the diffusion of the species participating in the reaction are evaluated.
\end{abstract}

Résumé-Les courbes de polarisation concernant l'oxydation électrochimique de l'iodure dissous dans des nitrates fondus sur une électrode à disque tournant de platine comprend deux ondes anodiques. La première appartient a un procèssus réversible de deux électrons et la deuxième à un procèssus réversible d'un seul électron. Une relation définie est établie entre les courants limites anodiques, indiquant que la deuxième onde anodique n'est pas indépendante de la première. Les paramètres relatifs à la diffusion des espèces qui participent à la réaction sont évalués.

Zusammenfassung-Die E/T-Kurven, die bei der elektrochemischen Oxydation von in geschmolzenen Nitraten gelöstem Jodid an einer rotierenden Scheibenelektrode aus Platin auftreten, umfassen zwei anodische Wellen. Die erste entspricht einem reversiblen Zweielektronen- und die zweite einem reversiblen Einelektronenprozess. Es wird ein genaues Verhältnis zwischen den anodischen Grenztrömen aufgestellt unter der Annahme, dass die zweite anodische Welle von der ersten nicht unabhängig ist. Es werden die Diffusionsparameter der Reaktionsteilnahmer angegeben.

\section{INTRODUCTION}

THE electrochemical kinetics of the iodine/iodide couple on platinum has been principally studied in aqueous solutions ${ }^{1-3}$ and in various organic solvents such as dimethylsulphoxide ${ }^{4-7}$ and acetonitrile. ${ }^{8}$ The electrochemical oxidation of iodide dissolved in nitrate melts was also studied on platinum ${ }^{9}$ and mercury ${ }^{10}$ electrodes. These results showed the qualitative occurrence of two anodic waves, the first exhibiting quite a reversible behaviour. The second anodic wave could not be interpreted in a reasonable way because of an appreciable irreproducibility of the results.

In the present work the anodic reaction has been studied on a platinum rotating disk electrode covering a wide range of experimental conditions. The information reported in the present paper confirms the already known interpretation of the first anodic wave and also permits a tentative interpretation of the second wave in terms of the reaction products formed at lower anode potentials. The sccond anodic wave corresponds to an electrochemical process that is purely convective-diffusion controlled.

\section{EXPERIMENTAL TECHNIQUE}

The electrolysis cell and platinum rotating disk electrode assemblies were the same as those described in an earlier publication.11 The electrode pre-treatment of the platinum rotating disk electrode $\left(0.07 \mathrm{~cm}^{2}\right)$ was also indicated in a previous paper. Its rotation speed was varied between 200 and $3000 \mathrm{rev} / \mathrm{min}$ by means of an electronic device that kept the rotation speed constant within 0.5 per cent. ${ }^{11}$

* Manuscript received 17 April 1970. 
A silver/silver(l) (0.07 M) reference electrode was employed. It was mounted with the usual Luggin-Haber capillary tip arrangement. The counter-electrode was a large-surface platinum wire placed in a separate compartment, the contact being made with a medium-grade fritted glass disk.

A.R. quality sodium nitrate, potassium nitrate, potassium iodide and iodine (Mallinckrodt and Carlo Erba) were used. The salts were carefully dried in a vacuum oven and kept under a dry atmosphere afterwards. When iodine was in the melt it was previously mixed with solid potassium iodide and the eutectic components. Later the mixture was warmed up slowly in the electrolysis cell until the melt reached the temperature of the experiments.

Each series of experiments comprised first the electrolysis of the nitrate eutectic to obtain blank $E / I$ curves. Later potassium iodide was added at different concentrations and the corresponding $E / I$ curves were recorded at different rotation speeds of the working electrode $(200,500,1000,2000$ and $3000 \mathrm{rcv} / \mathrm{min})$.

In the experiments where iodine was added, the molar $\mathrm{I}_{2} / \mathrm{I}-$ ratio was 2 , giving an acceptable excess of iodine if tri-iodide ion is formed.

The concentration of the reacting species was varied from $0.5 \times 10^{-3}$ to $5 \times 10^{-3} \mathrm{M}$ and was determined by weighing and by usual potentiometric analysis. Densities and viscosities of the melts employed were taken from previous publications. ${ }^{12.13}$ Experiments covered the temperature range from 234 to $314^{\circ} \mathrm{C}$.

\section{RESULTS}

Typical potentiostatic $E / I$ curves obtained at different experimental conditions without any correction except for the pseudo-ohmic overvoltage are shown in Figs. 1 and 2, the former including an $E / I$ curve of the pure melt at $200 \mathrm{rev} / \mathrm{min}$. The latter

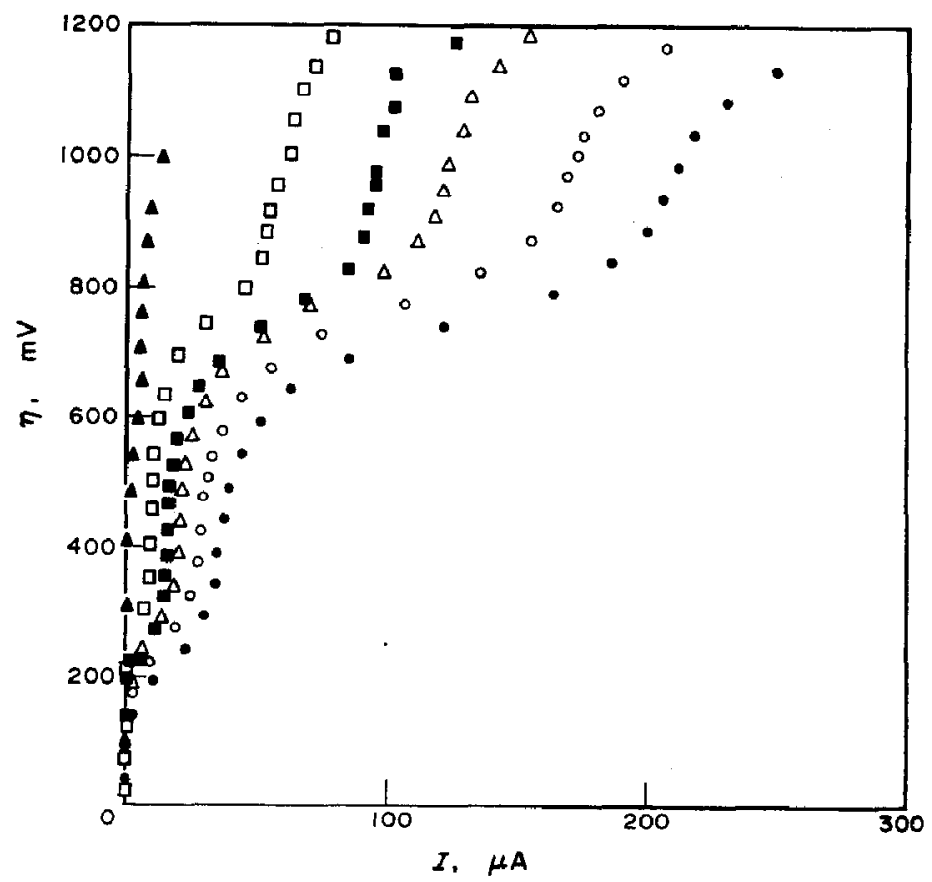

Fig. 1. Current/voltage curves at $240^{\circ} \mathrm{C}$. $c_{\mathrm{I}^{-}}, 1.08 \times 10^{-8} \mathrm{M}$. $\Delta$, Blank at $200 \mathrm{rev} / \mathrm{min} ; \square, 200 ; \square, 500 ; \Delta, 1000 ; 0,2000 ; \bullet, 3000 \mathrm{rev} / \mathrm{min}$. 


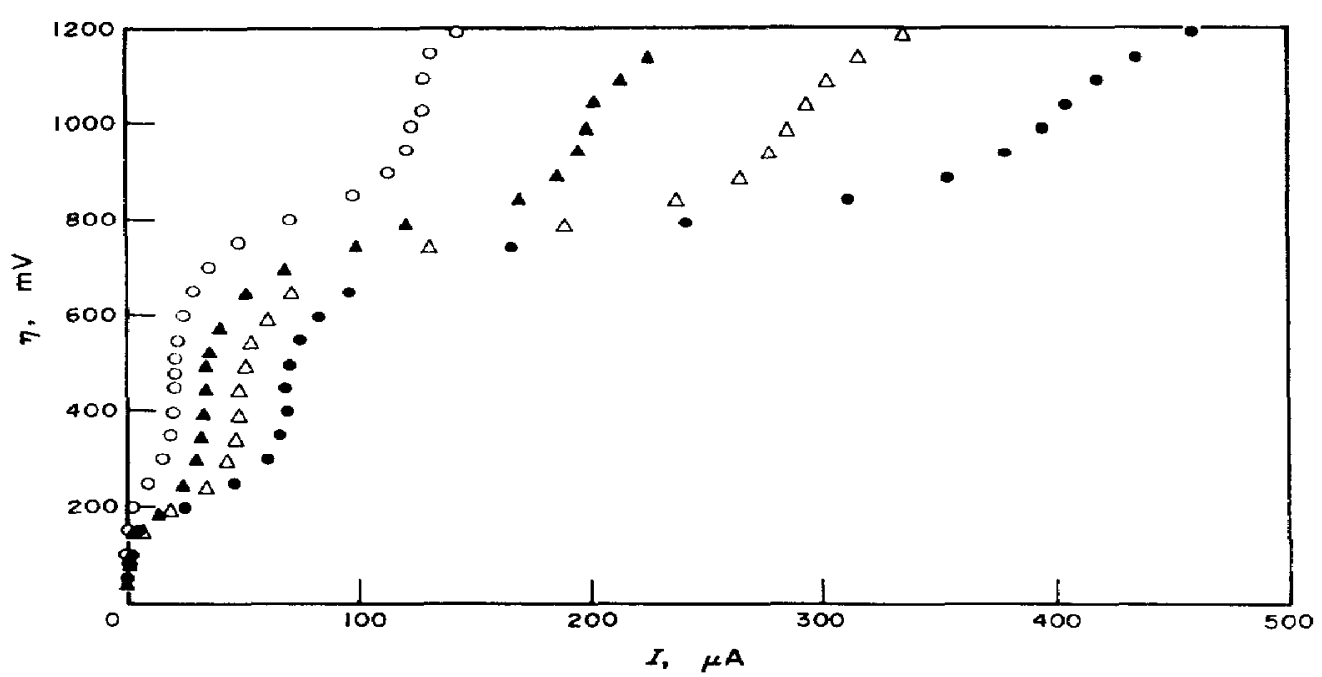

Fig. 2. Current/voltage curves at $240^{\circ} \mathrm{C} . c_{\mathrm{r}-}, 2 \cdot 27 \times 10^{-3} \mathrm{M}$.

0,$200 ; \Delta, 500 ; \triangle, 1000 ; 0,2000 \mathrm{rev} / \mathrm{min}$.

exhibits a limiting current corresponding to nitrite oxidation, comprising a half-wave potential, $E_{1 / 2}$ of $0.570 \mathrm{~V}$ at $240^{\circ} \mathrm{C}$. $E / I$ curves have been corrected for the pseudoohmic overvoltage, determined by switching the current off and recording the overvoltage decay from the oscilloscope screen. The overvoltage is defined with respect to the equilibrium potential of the working electrode when no current flows. The $E / I$ curves exhibit no hysteresis effect when retraced by decreasing the working electrode potential towards its equilibrium value.

The anodic $E / I$ curves corresponding to the iodide ion oxidation comprise two waves. The second wave appearing at higher anodic overvoltages is definitely distinct from the anodic wave related to nitrite oxidation. As already known, ${ }^{9}$ the residual nitrite wave is independent of any iodide addition to the system. The following experiment carried out at $257^{\circ} \mathrm{C}$ confirms this conclusion: the $E / I$ curve of the eutectic melt exhibited the nitrite limiting current at $16 \times 10^{-6} \mathrm{~A}$, corresponding to a nitrite concentration equal to $4 \times 10^{-4} \mathrm{M}$. Then, after the addition of potassium iodide, the two already reported waves were recorded. Finally sodium nitrite up to a total concentration in the melt of $8 \times 10^{-4} \mathrm{M}$ was added and the $E / I$ curve was again recorded. The increase observed in the second anodic wave was just $16 \times 10^{-6} \mathrm{~A}$. Thus, the experimental limiting current read for the second anodic wave was the sum of the limiting currents corresponding respectively to the oxidation of the nitrite and the oxidation of an active species related in some way to the iodide ion. Consequently, if there is any chemical reaction between iodide and nitrite it is practically negligible.

The anodic waves corresponding to the iodide oxidation are characterized by determined half-wave potentials, $\left(E_{1 / 2}\right)_{1}$ and $\left(E_{1 / 2}\right)_{2}$. Their difference agrees with values obtained earlier. ${ }^{9}$ The average $\left(E_{1 / 2}\right)_{2}$ value at $240^{\circ} \mathrm{C}$ is $0.740 \mathrm{~V}$. The $\left(E_{1 / 2}\right)_{1}$ values depend on the iodide concentration in the melt.

A definite relationship appears between the first and the second anodic limiting currents, the latter defined as $\left(I_{\mathrm{L}}\right)_{2}=\left(I_{\mathrm{L}}\right)_{\mathrm{T}}-\left(I_{\mathrm{L}}\right)_{1}$, the $\left(I_{\mathrm{L}}\right)_{\mathrm{T}}$ being the total second limiting current, both currents corrected for the blank. Table 1 contains values of $\left(I_{\mathrm{L}}\right)_{1}$ and $\left(I_{\mathrm{L}}\right)_{2}$ and the $\left(I_{\mathrm{L}}\right)_{2} /\left(I_{\mathrm{L}}\right)_{1}$ ratio at $240^{\circ} \mathrm{C}$. 
TAble 1. ANOdic limtting CURRents at $240^{\circ} \mathrm{C}$

\begin{tabular}{lrrrr}
\hline $\begin{array}{c}c_{\mathbf{I}^{-}} \\
\mathrm{mM}\end{array}$ & $\begin{array}{c}\omega \\
\mathrm{rev} / \mathrm{min}\end{array}$ & $\begin{array}{l}\left(I_{\mathrm{L}}\right)_{\mathbf{L}} \\
\mu \mathrm{A}\end{array}$ & $\begin{array}{c}\left(I_{\mathrm{L}}\right)_{\mathbf{2}} \\
\mu \mathrm{A}\end{array}$ & $\left(I_{\mathrm{L}}\right)_{\mathbf{2}} /\left(I_{\mathrm{L}}\right)_{\mathbf{1}}$ \\
\hline 0.503 & 200 & 4.4 & 16.6 & 3.8 \\
0.503 & 500 & 6.5 & 24.9 & 3.8 \\
1.08 & 200 & 8.8 & 36.2 & 4.1 \\
1.08 & 500 & 14.5 & 61.5 & 4.2 \\
1.08 & 1000 & 19.5 & 83.5 & 4.3 \\
1.08 & 2000 & 27.9 & 122.1 & 4.3 \\
1.08 & 3000 & 34.5 & 146.5 & 4.2 \\
2.27 & 200 & 20.5 & 89.5 & 4.3 \\
2.27 & 500 & 33.0 & 152.0 & 4.6 \\
2.27 & 1000 & 48.0 & 217.0 & 4.6 \\
2.27 & 2000 & 68.0 & 311.0 & 4.6 \\
4.54 & 200 & 42.0 & 183.0 & 4.3 \\
4.54 & 500 & 73.0 & 343.0 & 4.7 \\
4.54 & 1000 & 104.0 & - & - \\
4.54 & 2000 & 148.0 & - & - \\
\hline
\end{tabular}

At constant composition and temperature, both limiting currents related to the iodide oxidation increase linearly with the square root of the rotation speed, $\omega$, as shown in Figs. 3 and 4. At a constant rotation speed of the working electrode, both anodic waves also depend linearly on the iodide ion concentration, as depicted in

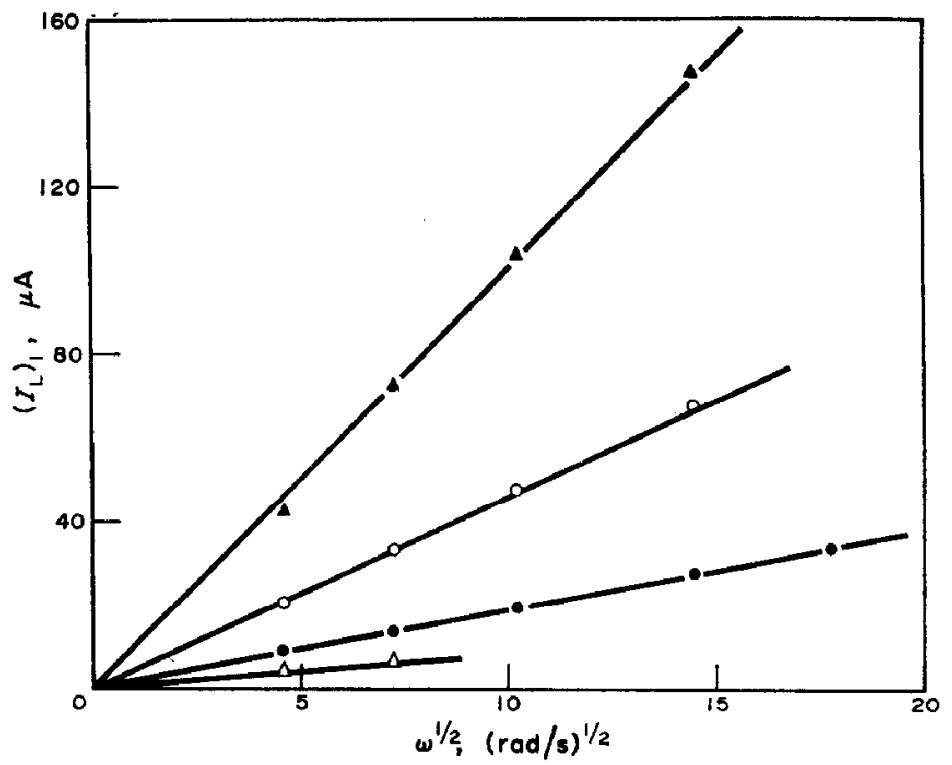

Fio. 3. Dependence of the first limiting current on $\omega^{1 / 2} ; 240^{\circ} \mathrm{C}$. $c_{\mathrm{I}^{-}}: \triangle, 0.503 ; 0,1.08 ; 0,2.27 ; \triangle, 4.54 \mathrm{mM}$. 


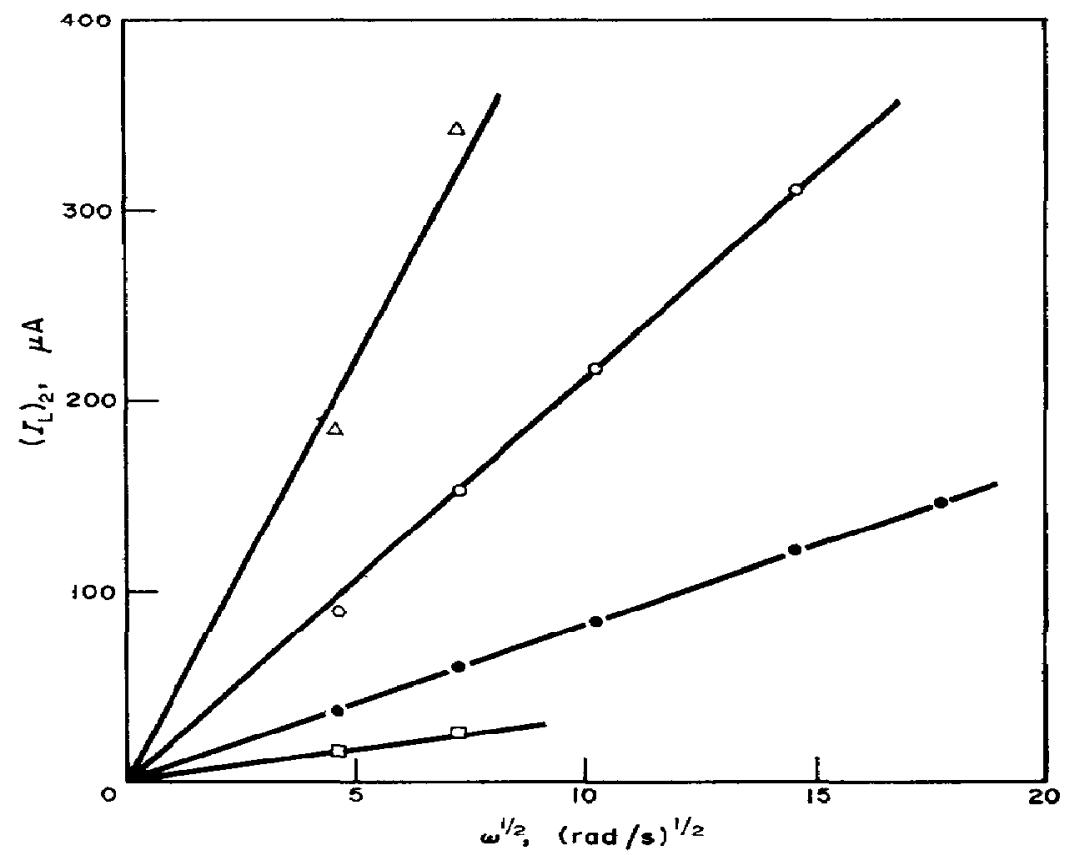

Fig. 4. Dependence of the second limiting current on $\omega^{1 / 2} ; 240^{\circ} \mathrm{C} . c$ is $\epsilon_{I}-/ 2$.

$$
\square, 0.251 ; 0,0.54 ; 0,1.13 ; \Delta, 2.27 \mathrm{mM} \text {. }
$$

Figs. 5 and 6 . The limiting currents plotted in these figures are properly corrected for the residual current of the solvent. The limiting currents increase with temperature, fitting Arrhenius plots, as shown in Fig. 7. The following figures were evaluated for

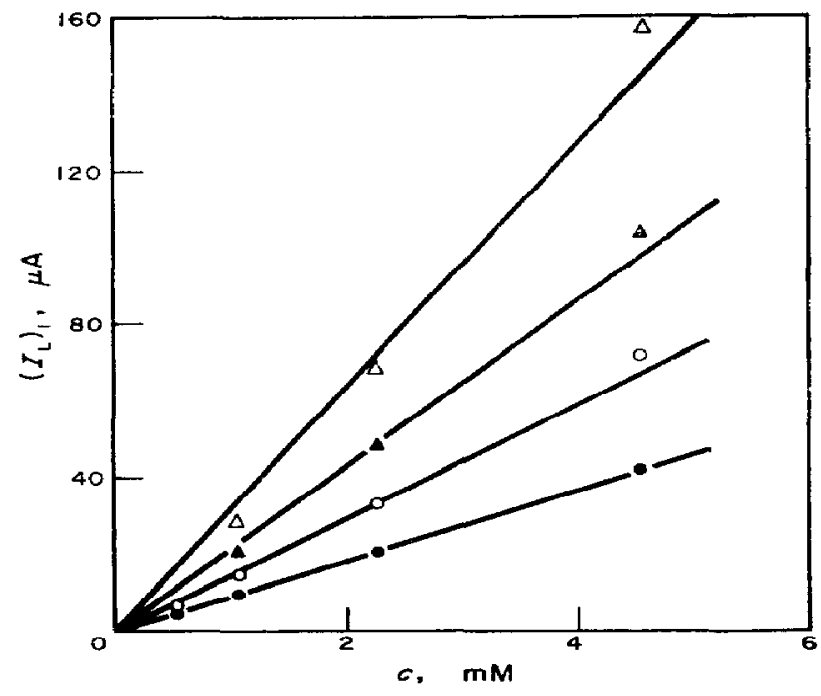

FIG. 5. Dependence of the first limiting current on iodide concentration; $240^{\circ} \mathrm{C}$.

0,$200 ; 0,500 ; \Delta, 1000 ; \triangle, 2000 \mathrm{rev} / \mathrm{min}$. 


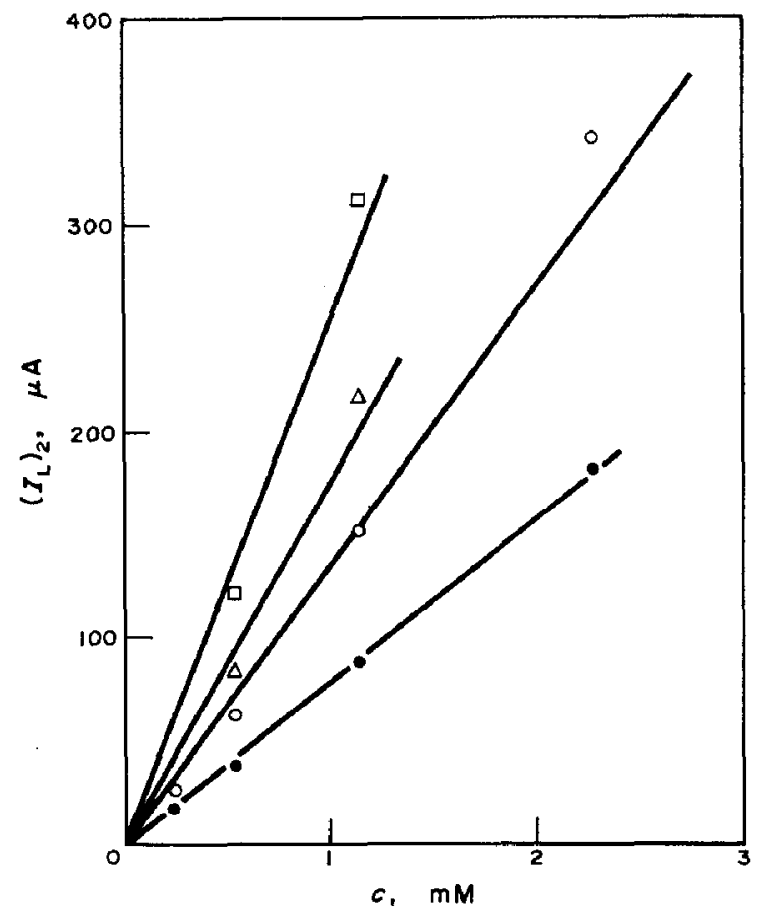

Fig. 6. Dependence of the second limiting current on $c_{\mathrm{I}}-12 ; 240^{\circ} \mathrm{C}$. 0,$200 ; 0,500 ; \triangle, 1000 ; \square, 2000 \mathrm{rev} / \mathrm{min}$.

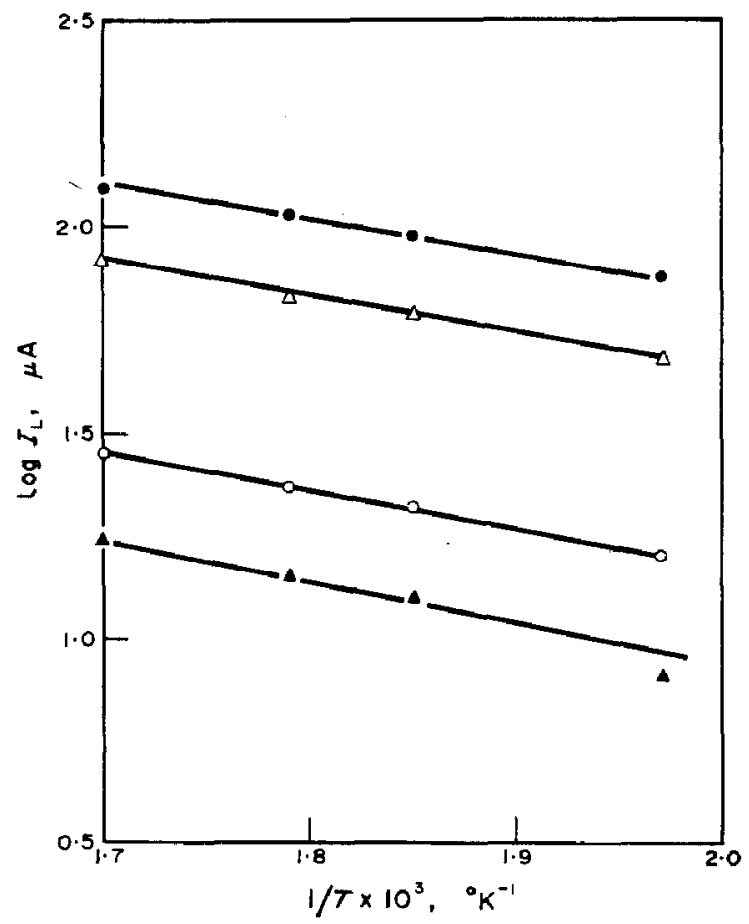

Fig. 7. Plots of $\log \left(I_{\mathrm{L}}\right)_{1}$ and $\log \left(I_{\mathrm{L}}\right)_{2}$ vs $1 / T$.

$\left(I_{\mathrm{L}}\right)_{1}: \Delta, 200 ; 0,500 \mathrm{rev} / \mathrm{min}$.

$\left(I_{\mathbf{L}}\right)_{2}: \triangle, 200 ; 0,500 \mathrm{rev} / \mathrm{min}$. 
the corresponding convective-diffusion processes:

from first anodic wave: $\Delta H_{1}{ }^{*}=4.4 \pm 0.5 \mathrm{kcal} / \mathrm{mole}$

from the second anodic wave: $\Delta H_{2}{ }^{*}=4.2 \pm 0.5 \mathrm{kcal} / \mathrm{mole}$.

Several experiments were made at $240^{\circ} \mathrm{C}$ to establish the effect of iodine addition, the results being shown in Table 2 . The $\left(I_{\mathrm{L}}\right)_{1}$ increases by 52 per cent at $200 \mathrm{rev} / \mathrm{min}$

TABle 2. EFFEct OF IODINE ADdITION

\begin{tabular}{|c|c|c|c|c|c|}
\hline \multicolumn{3}{|c|}{$\begin{array}{l}\text { Nitrate melt }+ \\
5.03 \times 10^{-4} \mathrm{M} \mathrm{KI}\end{array}$} & \multicolumn{3}{|c|}{ Nitrate melt +} \\
\hline$\stackrel{\omega}{\text { rev } / \mathrm{min}}$ & $\begin{array}{l}\left(I_{\mathbf{L}}\right)_{1} \\
\mu \mathrm{A}\end{array}$ & $\underset{\mu \mathrm{A}}{\left(I_{\mathrm{L}}\right)_{2}}$ & $\begin{array}{l}\omega \\
\mathrm{rev} / \mathrm{min}\end{array}$ & $\begin{array}{c}\left(I_{\mathrm{L}}\right)_{1} \\
\mu \mathrm{A}\end{array}$ & $\begin{array}{c}\left(I_{\mathbf{L}}\right)_{2} \\
\mu \mathrm{A}\end{array}$ \\
\hline $\begin{array}{l}200 \\
500\end{array}$ & $\begin{array}{l}4 \cdot 4 \\
6 \cdot 5\end{array}$ & $\begin{array}{l}16 \cdot 6 \\
24 \cdot 9\end{array}$ & $\begin{array}{l}200 \\
500\end{array}$ & $\begin{array}{r}6.8 \\
10 \cdot 4\end{array}$ & $\begin{array}{l}24 \cdot 7 \\
48 \cdot 0\end{array}$ \\
\hline
\end{tabular}

and 53 per cent at $500 \mathrm{rev} / \mathrm{min}$, and $\left(I_{\mathrm{L}}\right)_{2}$ also increases by 50 per cent at $200 \mathrm{rev} / \mathrm{min}$ and 64 per cent at $500 \mathrm{rev} / \mathrm{min}$.

Attempts to run some cathodic experiments in the presence of an excess of iodine were unsuccessful; the irreproducibility of the results allows no conclusion to be drawn about the possible electroreduction of iodine.

\section{INTERPRETATION AND DISCUSSION}

Kinetic behaviour of the anodic waves

The behaviour of the anodic $E / I$ curves resembles those of the reversible electrode processes. Therefore, let us try to interpret the first and second anodic waves respectively in terms of the following possible set of redox reactions,

Scheme I

and

$$
\begin{array}{lrl}
\text { First wave } & 2 \mathbf{I}^{-}=\mathbf{I}_{\mathbf{2}}+2 \mathrm{e}, \\
\text { Second wave } & \mathbf{I}_{\mathbf{2}}=\mathbf{I}_{\mathbf{2}}^{+}+\mathrm{e}, \\
& \left(\mathbf{I}_{\mathbf{2}}^{+}+\mathbf{I}^{-}=\frac{3}{2} \mathbf{I}_{\mathbf{2}}\right),
\end{array}
$$

Scheme II

$$
\begin{aligned}
& \text { First wave } \quad 2 \mathrm{I}^{-}=\mathrm{I}_{2}+2 \mathrm{e} \text {, } \\
& \left(\mathrm{I}^{-}+\mathrm{I}_{2}=\mathrm{I}_{3}^{-}\right) \text {, } \\
& \text { Second wave } \quad 2 \mathrm{I}_{3}^{-}=3 \mathrm{I}_{2}+2 \mathrm{e} \text {. }
\end{aligned}
$$

Scheme $I$ involves the formation of the $I_{2}+$ ion, which in the presence of iodide would be in equilibrium with iodine in the bulk of the melt, probably through an intermediate species such as $\mathbf{I}_{\mathbf{3}}$.

Scheme II involves the participation of the tri-iodide ion in equilibrium with iodide and iodine at the interfacial region, as is the case for the iodine/iodide electrode in water and in various organic solvents. ${ }^{1-8}$ Spectroscopic studies ${ }^{14}$ indicate the existence of tri-iodide in molten systems, such as chloride melts, but the present experiments are not conclusive as far as a clear participation of tri-iodide in the electrochemical reaction occurring in the nitrate melt.

Assuming a reversible behaviour of the electrode reactions, the corresponding 
Nernst equations are

and

$$
\begin{aligned}
& E_{\mathrm{I} \mathrm{Q}}=E_{\mathrm{Ia}}^{\circ}+\frac{R T}{2 F} \ln \frac{\left(a_{\mathrm{I}_{2}}\right)_{\mathrm{B}}}{\left(a_{\mathrm{I}}\right)_{\mathrm{g}}^{2}}, \\
& E_{\mathrm{Ib}}=E_{\mathrm{Ib}}^{\circ}+\frac{R T}{F} \ln \frac{\left(a_{\mathrm{I}_{\mathrm{g}}}\right)_{\mathrm{B}}}{\left(a_{\mathrm{I}_{\mathrm{g}}}\right)_{\mathrm{g}}}
\end{aligned}
$$

$$
E_{\mathrm{IIc}}=E_{\mathrm{IIc}}^{\circ}+\frac{R T}{2 F} \ln \frac{\left(a_{\mathrm{I}_{2}}\right)_{\mathrm{s}}{ }^{3}}{\left(a_{\mathrm{I}_{\mathrm{s}}}\right)_{\mathrm{s}}{ }^{2}},
$$

where the $E^{\circ} s$ are the standard electrode potentials of the reactions and $a_{1}$ refers to the activity of the $i$ species at the electrode surface.

Let us consider the first anodic wave and express (1) in terms of cd,

$$
E_{\mathrm{Ia}}=E_{\mathrm{Ia}}{ }^{\prime}-\frac{2 \cdot 3 R T}{2 F} \log \frac{\left[\left(i_{\mathrm{r}}\right)_{1}-i\right]^{2}}{i},
$$

where $E^{\prime}$ includes the ratio of the activity and diffusion coefficients of the species entering the reaction.

Equation (4) has been tested in Fig. 8. Experimental results fit the theoretical line of slope $2 \cdot 3(R T / 2 F)$ reasonably well. This fact, in addition to the linear dependence of

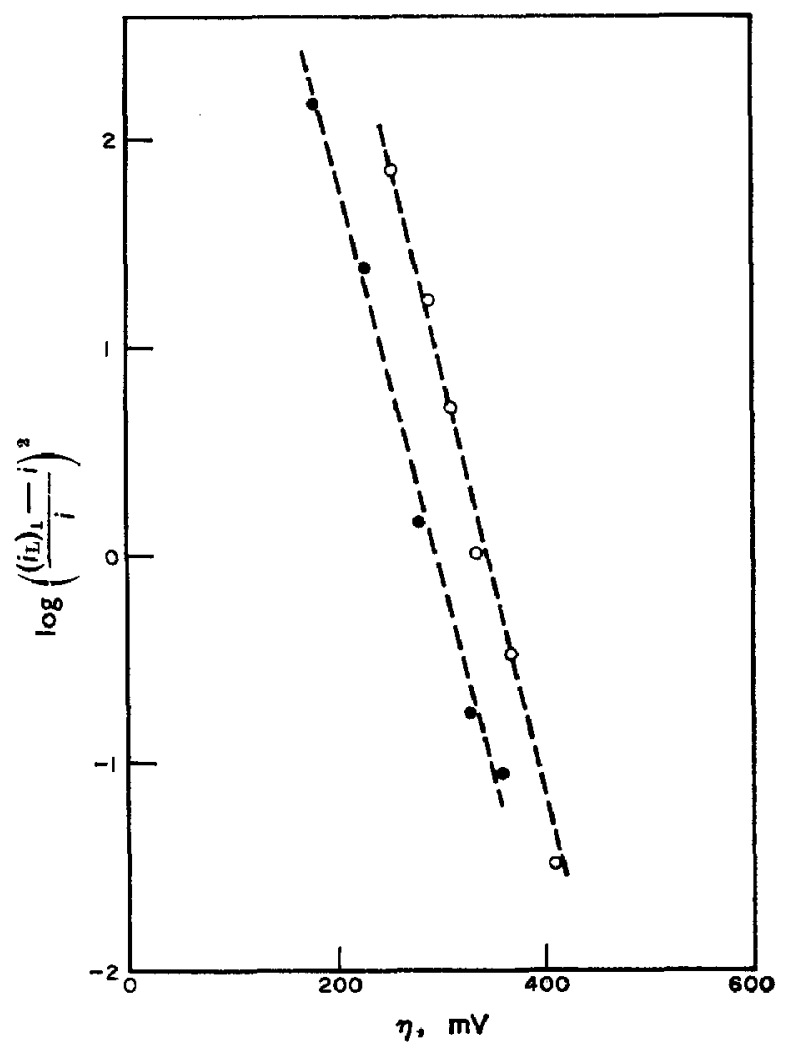

Fig. 8. Plot of equation (4).

$0,234^{\circ} \mathrm{C}, 200 \mathrm{rev} / \mathrm{min} ; c_{\mathrm{I}}-1.08 \mathrm{mM}$.

, $240^{\circ} \mathrm{C}, 500 \mathrm{rev} / \mathrm{min} ; c_{\mathrm{I}}-1.08 \mathrm{mM}$. 
$\left(I_{L}\right)_{1}$ on $\omega^{1 / 2}$, of $\left(I_{L}\right)_{1}$ on iodide concentration and the dependence of $\left(E_{1 / 2}\right)_{1}$ with the logarithm of $\left(I_{\mathrm{L}}\right)_{1} / 2$, is a clear indication of the reversible character of the first anodic wave.

Let us consider now the second anodic wave. The $E / I$ curves corresponding to reaction Ib and IIc, after replacing the activity terms in the Nernst equations in terms of cd, are expressed by

and

$$
E_{\mathrm{Ib}}=E_{\mathrm{Ib}}{ }^{\prime}-\frac{2 \cdot 3 R T}{F} \log \frac{\left[\left(i_{\mathrm{L}}\right)_{2}-\left(i_{\mathrm{L}}\right)_{1}\right]-\left[i-\left(i_{\mathrm{L}}\right)_{1}\right]}{\left[i-\left(i_{\mathrm{L}}\right)_{1}\right]}
$$

$$
E_{\mathrm{IIc}}=E_{\mathrm{IIc}}^{\prime}+\frac{2 \cdot 3 R T}{2 F} \log \frac{\left[\left(i_{\mathrm{L}}\right)_{2}-i\right]^{3}}{\left[i-\left(i_{\mathrm{L}}\right)_{1}\right]^{2}}
$$

where the $E$ 's are defined as above. Equations (5) and (6) are compared to experimental results in Fig. 9; it clearly emerges that in spite of the relatively higher errors involved in the second wave data, the results are reasonably well approximated by (5).

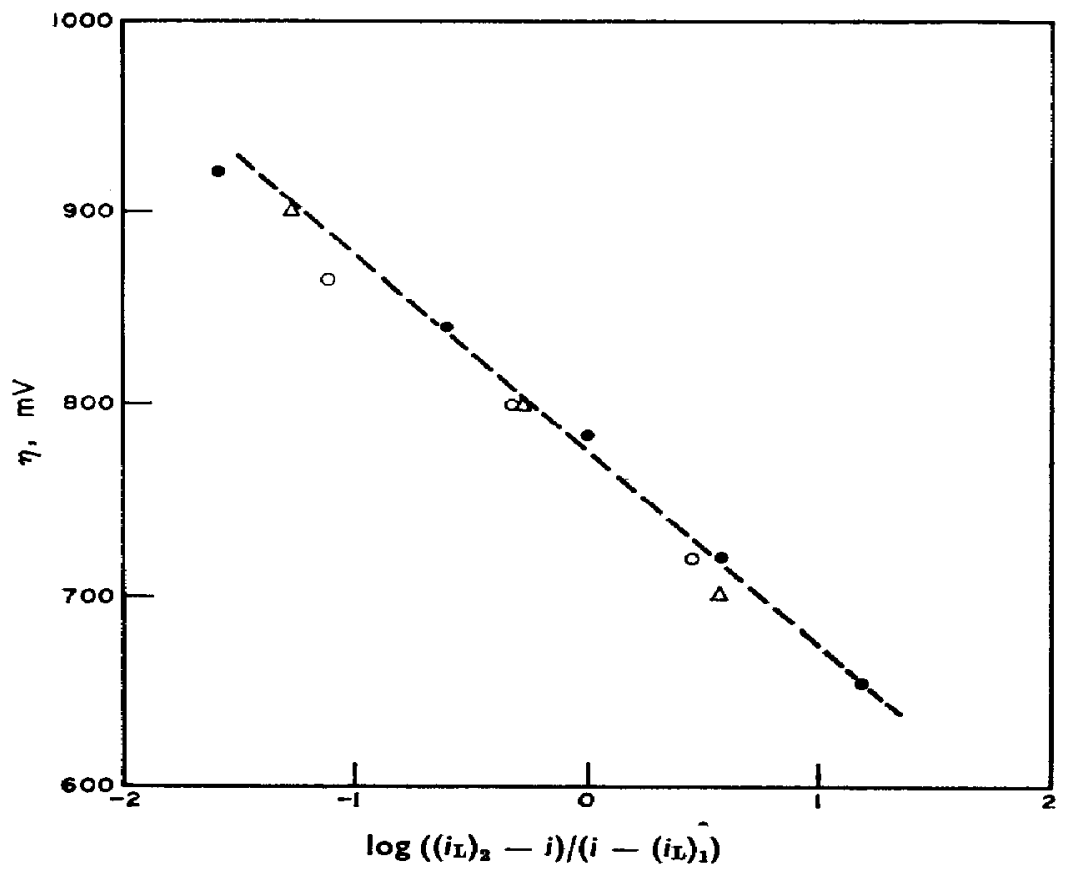

FiG. 9. Plot of equation (5); $240^{\circ} \mathrm{C}$.

$$
\begin{aligned}
& 0, c_{\mathrm{I}}-0.503 \mathrm{mM} ; 200 \mathrm{rev} / \mathrm{min} ; \\
& 0, c_{\mathrm{I}}-1.08 \mathrm{mM} ; 1000 \mathrm{rev} / \mathrm{min} ; \\
& \triangle, c_{\mathrm{I}}-1.08 \mathrm{mM}, 2000 \mathrm{rev} / \mathrm{min} .
\end{aligned}
$$

The straight line corresponds to the theoretical slope $(2 \cdot 3 R T / F)$.

This fact does not necessarily mean that the second anodic wave is actually represented by reaction $I b$, but it is by an equilibrium that yields the same kind of expression. Thus, a Nernst equation formally analogous to (5) can also be obtained on the assumption that the second wave involves tri-jodide in the equilibrium

$$
\begin{aligned}
\mathrm{I}_{3}-\mathrm{I}_{3}+\mathrm{e}, \\
{\left[2 \mathrm{I}_{3} \rightleftarrows 3 \mathrm{I}_{2}\right] . }
\end{aligned}
$$


However no sound evidence exists to justify reaction (IIIa). Unfortunately no reliable cathodic data could be obtained to decide the participation of tri-iodide in the electrode processes.

The reversible behaviour is again in agreement with the linear dependence of the second anodic limiting current both on the square root of rotation speed of the working electrode and on the iodide concentration, and with the independence of the corresponding half-wave potential on concentration and rotation speed. For comparison it has been assumed that the concentration of the reacting species at the interface is practically one half the iodide concentration there, as shown in Fig. 6. Therefore, it can be concluded that the electrode process related to the second anodic wave is to be considered as reversible, involving the transfer of one electron per mole of reacting species. No further kinetic conclusions can be derived at present from the $E / I$ curves.

Evaluation of diffusion coefficients of reacting species

The linear $I_{\mathrm{L}} v s \omega^{1 / 2}$ plot is obeyed for any process occurring at the rotating disk electrode under pure convective-diffusion control. The application of the theoretical rate equations derived for this circumstance thus allow the evaluation of the diffusion coefficient. ${ }^{15}$ For the purpose, Newman's equation was employed, ${ }^{16}$

$$
i_{\mathrm{L}}=\frac{0.62048 z_{1} F D_{\mathrm{i}}^{2 / 3} \nu^{-1 / 6} \omega^{1 / 2} c_{\mathrm{i}}}{1+0.2980\left(\frac{D_{\mathrm{i}}}{\nu}\right)^{1 / 3}+0.14514\left(\frac{D_{\mathrm{i}}}{\nu}\right)^{2 / 3}},
$$

where $D_{i}$ is the diffusion coefficient of reacting species $i$ in $\mathrm{cm} / \mathrm{s}, \omega$ the rotation speed of the working electrode in $\mathrm{rad} / \mathrm{s}, \nu$ the kinematic viscosity in $\mathrm{cm}^{2} / \mathrm{s}, c_{1}$ the concentration of the reacting species $\mathrm{i}$ in mole $/ \mathrm{cm}^{3}$, and $z_{\mathrm{i}}$ the number of electrons participating in the reaction per mole of $i$. The other symbols have the usual meanings. Average diffusion coefficients evaluated with (7) at $240^{\circ} \mathrm{C}$ are $D_{1}=4.02 \times 10^{-6} \mathrm{~cm}^{2} / \mathrm{s}$ and $D_{2}=1.05 \times 10^{-4} \mathrm{~cm}^{2} / \mathrm{s}$. The latter was calculated by taking a concentration of the reacting species equal to one half the initial iodide concentration, and $z=1$. No appreciable concentration dependence of the diffusion coefficients could be established.

From the Arrhenius plots shown in Figs. 10 and 11, the experimental activation

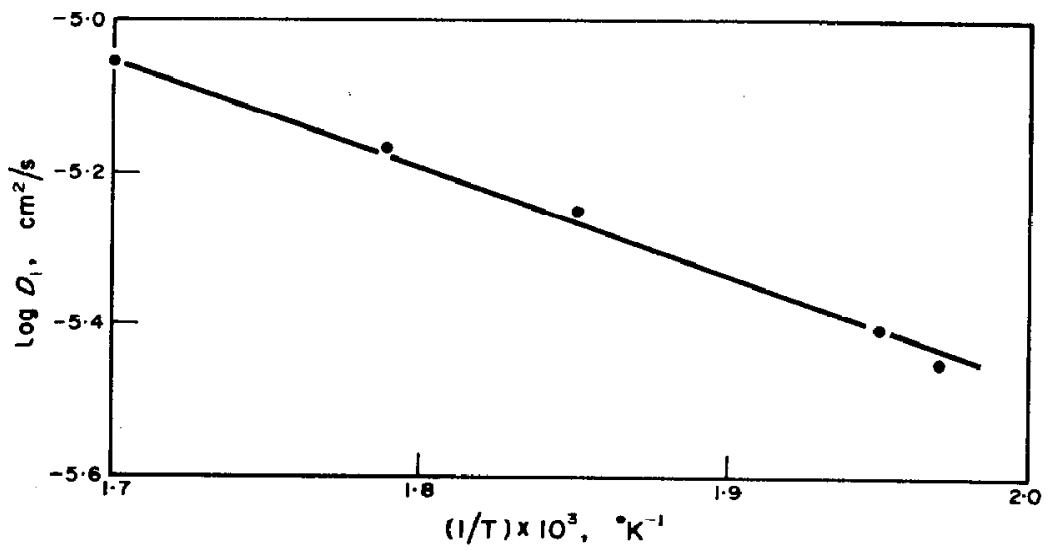

Fig. 10. Plot of $\log D_{1}$ vs $1 / T$. 


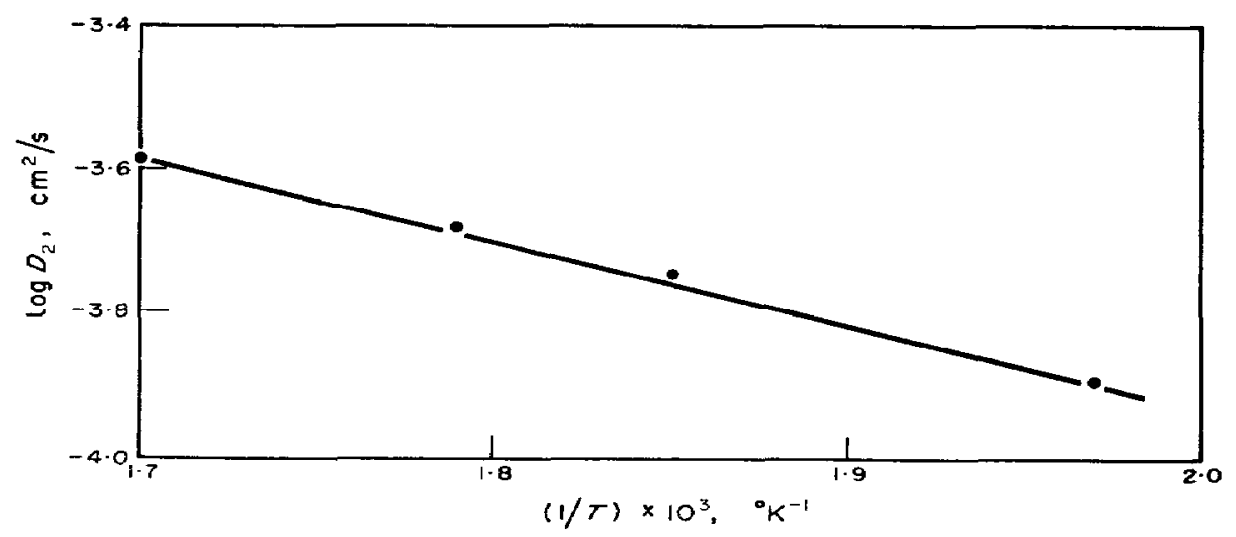

FIG. 11. Plot of $\log D_{2}$ os $1 / T$.

energies for diffusion are respectively $\Delta H_{D_{1}}^{*}=6.4 \pm 0.5 \mathrm{kcal} / \mathrm{mole}$ and $\Delta H_{D_{2}}^{*}=$ $5.1 \pm 0.5 \mathrm{kcal} / \mathrm{mole}$.

The $D_{2}$ value, which comprises a very high diffusion coefficient of the species reacting in the second anodic wave, can be related either to iodine or tri-iodide, since no definite evidence for any of the two species can be ascertained at present.

From solubilities and transport properties studies of halogens in molten halides, ${ }^{17}$ such as for instance chlorine in molten chlorides, it was found that the diffusion coefficient of chlorine was greater than that of silver(I) ion in LiCl-KCl eutectic at $400^{\circ} \mathrm{C}$, by a factor of 3 or 4 . According to Van Norman and Tivers, ${ }^{17}$ one explanation of the high diffusion coefficient of chlorine is that the gas dissolves in the melt forming trichloride ions, so that a tri-chloride ion by a sort of Grotthus-type chain conduction transfers a $\mathrm{Cl}_{2}$ molecule to an adjoining chloride ion which then becomes the trichloride ion, whereupon the process repeats itself. This transport mechanism requires the exchange of chloride ions with chlorine gas which, for the case considered, occurred as a rapid process in molten $\mathrm{PbCl}_{2}-\mathrm{KCl}{ }^{18}$ This interpretation of the diffusion coefficients can in principle be extended to either iodine or tri-iodide ion in molten nitrates. It is evident, however, that further studies are required for a fuller understanding of these transport processes.

Finally, the knowledge of the experimental activation energies for diffusion and viscosity permits to check the experimental activation energy for the convectivediffusion processes, since

$$
\Delta H_{\mathrm{L}}^{*}=\frac{2}{3}\left(\Delta H_{D}^{*}\right)-\frac{1}{6}\left(\Delta H_{v}^{*}\right) .
$$

As $\Delta H_{v}^{*}=-3.7 \pm 0.5 \mathrm{kcal} / \mathrm{mole}^{19}$ the application of $(8)$ yields $\left(\Delta H_{\mathrm{L}}^{*}\right)_{1}=$ $4.8 \pm 0.5 \mathrm{kcal} / \mathrm{mole}$ and $\left(\Delta H_{\mathrm{L}}^{*}\right)_{2}=4.0 \pm 0.5 \mathrm{kcal} / \mathrm{mole}$, in reasonably good agreement with the experimental results.

Acknowledgement-This research was done under U.S.A.F. Grant (AFOSR-69-1780) and with the support of the Consejo Nacional de Investigaciones Cientificas y Técnicas of Argentina.

\section{REFERENCES}

1. K. J. VetTER, Z. phys. Chem. 199, 22, 285 (1952).

2. J. D. RIDDIFORD and A. C. NewSON, J. electrochem. Soc. 108, 695 (1961).

3. A. C. Newson and J. D. RIDdiford, J. electrochem. Soc. 108, 699 (1961). 
4. M. C. Giordano, J. C. BazÁn and A. J. Arvía, Electrochim. Acta 11, 741 (1966).

5. M. C. Giordano, J. C. BAzÁn and A. J. ArvtA, Electrochim. Acta 11, 1553 (1966).

6. M. C. Giordano, J. C. BazÁn and A. J. ARvIA, Electrochim. Acta 12, 723 (1967).

7. A. J. ArviA, M. C. Giordano and J. J. Podestá, Electrochim. Acta 14, 389 (1969).

8. V. A. Macagno, M. C. Giordano and A. J. Arvfa, Electrochim. Acta 14, 335 (1969).

9. H. S. Swofford, Jr. and J. H. Propp, Anal. Chem. 37, 974 (1965).

10. M. Francin, S. MARTINI and C. MonfrinI, Electrochim. Metallorum 2, 325 (1967).

11. M. E. Martins, G. Paus, A. J. Calandra and A. J. Arvia, Anales Asoc. quim. arg., 57, 61 (1969).

12. Metals Reference Book, ed. C. J. SMTTHELLS, p. 670. Butterworths, London (1962).

13. C. E. FAwSITT, J. chem. Soc. 93, 1299 (1908).

14. J. GreEnaerg and B. R. SundheIM, J. chem. Phys. 29, 1029 (1958).

15. A. J. ARvía and S. L. Marchiano, in press.

16. J. Newman, J. phys. Chem. 70, 1327 (1966).

17. J. D. VAN Norman and R. TIvers, Symp. Charact. and Analysis in Molten Salts. Am. Chem. Soc. 156th Meeting (1968).

18. M. Kowalski and G. W. Harrington, Inorg. nucl. Chem. Lett. 3, 121 (1967).

19. M. E. Martins, Thesis, La Plata (1968). 